\title{
The Change of Mental Process in the Translation of Ronggeng Dhukuh Paruk from Bahasa Indonesia into English
}

\author{
Khristianto \\ Faculty of Letters \\ the University of Muhammadiyah Purwokerto \\ kristian.topz@gmail.com
}

\begin{abstract}
Mental process (thinking activities) is a part of transitivity system, representing language meaning as a symbol or representation meaning. In translation, this meaning is the most important, determining whether or not a clause is translated correctly. It means a sentence with a mental-process predicate will be right only, if it is realized in the same process. This paper tries to prove this notion, by exploring a novel translation from Bahasa to English. It employs Halliday's transitivity as a means to contrast a source text (T1) and a target text (T2).

Based on the analysis, it is found out that some mental processes in the novel are translated into another process. Perception and affection are two subtypes of mental process which are translated into relational process and material process. The change into relational process is identified in many cases; though most of the data are translated into a the same mental process. This change is triggered by the strategies of modulation and transposition. Meanwhile, there is only a single case of change into a material process, which is resulted from the different realization, literal to metaphorical expression. Thus, this proves that the change of a process in a clause does not necessarily entail a change of meaning.
\end{abstract}

Keywords: mental process, perception, affection, transitivity, meaning realization. 


\section{Abstact}

Proses mental (thinking activities) merupakan bagian dari sistem transitivas, yang mewakili makna bahasa sebagai simbol atau makna representasi. Dalam penerjemahan, makna ini adalah makna terpenting, yang menentukan benar/salah. Artinya satu klausa dengan predikat bertipe proses mental hanya akan benar bila diterjemahkan menjadi klausa dengan jenis proses yang sama. Tulisan ini akan membuktikan apakah dalil ini selalu benar, dengan mengkaji penerjemahan novel RDP dari bahasa Indonesia ke bahasa Inggris. Teori transitivitas Halliday diterapkan sebagai perangkat kontrastif realisasi proses mental dalam teks asli (T1) dan teks terjemahan (T2). Dari analisa yang dilakukan, ditemukan sebagian klausa proses mental pada T1 diterjemahkan dengan klausa berpredikat bukan proses mental. Proses mental yang mengalami perubahan adalah subtype persepsi dan afeksi. Mereka direalisasikan menjadi proses material dan rasional. Perubahan menjadi proses relasional merupakan perubahan yang dominan. Perubahan ini dipicu oleh strategi penerjemahan modulasi dan transposisi. Sementara perubahan menjadi proses material disebabkan oleh pengalihan gaya ungkap dari harfiah menjadi metaforis. Terbukti bahwa perubahan proses yang terjadi tidak secara otomatis mengubah makna atau pesan.

Kata kunci: proses mental, persepsi, afeksi, transitivitas, realisasi makna.

\section{Introduction}

Mental process refers to a category of activities which may be embodied in a clause. It is just one of the six main types of the processes formulated by Halliday (1985). Mental process is a type of activity represented in a language to construe "our experience of the world of our own consciousness" (Halliday \& Matthiessen, 2004: 197). The verbs like know, hate, like and the like are the examples. A clause bearing the words will always depict "quantum of change in the flow of events taking place in our own consciousness" (ibid). 
A clause in a certain type of process in a language logically has to be realized in another clause with similar type when it is translated into another language. However, a different semiotic system may lead a translator to change the processes type due to some determining factors. This paper addresses the issue of process type change in a translation involving Indonesian-English, particularly the mental process type.

Translation is a process of meaning extraction from a text and put the meaning into another. With meaning as its commodity, translation is a communication involving at least two semiotic systems, always operating in a certain context. Text, according to Halliday dan Hasan (1985, Tou:1992:14), is a collection of meaning codified in words and structures. It is a process and and product of social meaning in a situational context (ibid:15). Further, they explain that a text presents in variables determining their presentation manifestation. Text is always influenced by field, tenor, and mode, and also its situational and cultural contexts.

A translation work is a realization of single meaning in another language. Thus, the meaning, which covers three types of meanings, is represented in different verbal semiotic systems. In translation, the most prominent meaning, "highest value", to be maintained is the ideational meaning; when TT fails to match ideationally to ST, it will not be viewed as a translation (Halliday in Manfredi, 2008: 64-65). This is general for translation work. A real value as the most important one to be maintained is by context. In a certain case, it is very possible that another meaning, either interpersonal or textual, bears the highest value. Halliday sums the criteria of a good translation as, "a text which is a translation (i.e. is equivalent) in respect of those linguistic features which are most 
valued in the given translation context." A translator surely will try to realize all those three meanings from the ST in his/her work.

Thus, it can be said that translation texts are representation of one meaning in different languages. Textual realizations there are comparable linguistic phenomena as a way to understand the working semiotic systems. Each text involved in translation is created for one meaning to equalize the source work. If it is a novel, the translation should be the same novel in other language(s). This means that the textual realization there illustrates how a language operates for the meaning, and the comparative study on languages in translation can represent their linguistic characteristics. The use of translation text as the source of language description has been done by many researches (Yuli \& Yushan: 2012, Lian \& Jiang: 2014, Khristianto: 2014). The first two compare English-Chinese, and the third describes Indonesia, Javanese and English.

Another research exploring modality in translation is done by Mao, Li and Xue (2014). They analyzed a drama, Major Barbara, and its two Chinese versions as the data corpus to compare the modality system in English and Chinese. A study investigating a different facet of functional linguistics was done by Lavid, Arus, and Moraton (2009). It focused on thematisation between English and Spanish, using bidirectional translated text in the languages on different genres. Similar to previous studies, this study also applied an approach of contrastive functional description. In English-Indonesian texts, the study on thematic structure has been done by Budiman (2006) and Wulandari (2013). Both took Obama's speech, the former used Obama's first inaugural speech and the latter selected Obama's speech delivered in his visit to Indonesia 
University, as the translation data to see how the theme structure in two versions are different from one to another.

This paper will focus only on the variation of mental process realization from Indonesian into English. The data sources are the novels of Ronggeng Dhukuh Paruk (Tohari (1982), (2003), and (2006)) in two different languages, Bahasa Indonesia and English. This applies Halliday's transitivity to see the changes of mental process category in the clauses collected from the sources.

\section{Discussion}

As mentioned earlier, mental process is a process characterized by the activity occurring in our mind / consciousness. It includes perception, cognition, and affection. These mental processes in the data analyzed are also found to have a variation or change into other types of processes. Each category of the mental process does change into another. The first process of "perception" has been changed into "doing" and "relational".

1. Makin sering terdengar suara tangis bayi.

\begin{tabular}{|l|l|l|}
\hline Makin sering & terdengar & suara tangis bayi \\
\hline cir: manner & seeing proc. & phenomenon \\
\hline
\end{tabular}
The cry of a baby pierced the silence
\begin{tabular}{|l|l|l|}
\hline The cry of a baby & pierced & the silence \\
\hline actor & doing proc. & goal \\
\hline
\end{tabular}

The datum 1 above shows the process of perception or the so-called process of seeing which is represented by the word "terdengar" ('sound') turned out into a process with the verb "pierced", which is "material" type of process. Material process is "concerned with our experience of the material world" (Halliday \& Matthiessen, 2003:197). "Pierce" means a 
physical activity, though it is used metaphorically. Meanwhile, the word "sound" clearly represents the activities carried out through the sense of hearing, a perception.

A change from mental to material is a big leap, considering both are very different. It is like a change from one extreme to another in a long continuum. The big difference between these processes can be seen in their position on Halliday's diagram (1994:108). The reason behind this drastic change is the different style of expression in $\mathrm{T} 1$ and $\mathrm{T} 2$. $\mathrm{T} 1$ puts the meaning literally; T2 evokes the same meaning in a metaphor. Thus, though the wording is different, T2 still maintains the same meaning.

Another change of the perception process is into a relation process, either attributive or identifying. "Relational clauses serve to characterize and to identify" (Halliday \& Matthiessen, 2003:210). As shown in the datum 2, the clause in T1 has a verb "look" representing a perception process done by "visual" sense. It is then changed into a main verb form, to be "was" or linking verb "show" that both embodies a process-attributive relations. Similar transitions are also seen in the datum 3 and 4 with the changes of "tampak" ("seen") into "was" and "terdengar" ('is heard') into "was".

2 Tidak tampak tanda Srintil lelah

\begin{tabular}{|c|c|c|c|c|c|c|c|}
\hline \multicolumn{2}{|c|}{ Tidak } & \multicolumn{3}{|c|}{ tampak } & \multicolumn{3}{|c|}{ tanda Srintil lelah } \\
\hline & & \multicolumn{2}{|c|}{ seeing proc. } & \multicolumn{4}{|c|}{ phenomenon } \\
\hline \multicolumn{8}{|c|}{ If Srintil was tired, she showed no evidence of it } \\
\hline \multirow[t]{2}{*}{ If } & \multicolumn{2}{|c|}{ Srintil } & was & tired & she & showed & $\begin{array}{l}\text { no } \\
\text { evidence... }\end{array}$ \\
\hline & \multicolumn{2}{|c|}{ carrier } & $\begin{array}{l}\text { attributive } \\
\text { proc. }\end{array}$ & attribute & carrier & $\begin{array}{l}\text { attributive } \\
\text { proc. }\end{array}$ & attribute \\
\hline
\end{tabular}


Another case is seen from datum 4 in which a main verb "melihat" "to see", perceiving through visual sense, is transferred into "look" that serves as a linking verb to be synonymous with to be; it serves to "characterize" the subject (carrier). The verb as predicate connects the carrier to its complement or attribute. This change is a result of the transposition (Vinay and Darbelnet in Newmark, 1988:86) from an active into a passive construction.

It shows a significant transposition from $\mathrm{T} 1$, which is packed in simplex clause, into a T2 complex clause. For this Newmark (1988:87) further explains, "Certain transpositions appear to go beyond linguistic differences and can be regarded as general options available for stylistic consideration. Thus a complex sentence can normally be converted to a co-ordinate sentence or to two simple sentences..." (my emphasis). This way provides evidence that a translator has a space to negotiate; he/she can go in another path the author does not take-as long as the writer's meaning is preserved in the translation.

3. Dari tempatnya yang tinggi kedua burung bangau itu melihat Dukuh Paruk sebagai sebuah gerumbul kecil di tengah padang yang amat luas.

\begin{tabular}{|l|l|l|l|}
\hline $\begin{array}{l}\text { Dari } \\
\text { tempatnya... }\end{array}$ & $\begin{array}{l}\text { kedua } \\
\text { burung... }\end{array}$ & melihat & $\begin{array}{l}\text { Dukuh } \\
\text { Paruk... }\end{array}$ \\
\hline cir & senser & seeing proc. & phenomenon \\
\hline
\end{tabular}

From the high vantage point of the two herons, the village of Paruk would have looked like a small thicket in the middle of a broad field.

\begin{tabular}{|l|l|l|l|l|}
\hline $\begin{array}{l}\text { From the } \\
\text { high... }\end{array}$ & the village & would... & $\begin{array}{l}\text { looked } \\
\text { like }\end{array}$ & $\begin{array}{l}\text { a small } \\
\text { thicket }\end{array}$ \\
\hline cir & carrier & & $\begin{array}{l}\text { attributive } \\
\text { proc. }\end{array}$ & attribute \\
\hline
\end{tabular}


What happen here is the change in point of view, modulation strategy (Vinet and Darbelnet in Baker and Saldanha, 2009:582). They say, '[a] translation method consisting of changing a point of view, an evocation, and often a category of thought' (Vinay and Darbelnet 1995:346). T1 positions the bird as the acting subject and the village as the object; in T2, they are only a point from which the village is seen, and the village is the subject of passive-like construction using linking verb, "look". This modulation has made the shift on process type.

In addition to the change into relational process of attributive subtype, the perception process is also found to be translated into an identifying relational process. Some sample data showing such change is as follows. The original clause with a verb of "mendengar" ('hear'), which clearly shows the activity of the auditory sense, is then embodied in a target clause into a process of "being"; it shows an identification. One way to prove the identification process is reversibility, the possibility of a reversal of the position of the subject-complement, because either complement or subject refers to a single referent. Here again, it can be recognized an obvious transposition involved; the strategy is the culprit for the shift on the process type.

4. Tetapi Santayib mendengarnya sebagai hiruk-pikuk suasana ribuan monyet di pekuburan Dukuh Paruk.

\begin{tabular}{|l|l|l|l|l|}
\hline Tetapi & Santayib & mendengar & -nya & sebagai... \\
\hline & senser & $\begin{array}{l}\text { seeing } \\
\text { proc. }\end{array}$ & phenomenon & cir. \\
\hline
\end{tabular}

all Santayib registered was the cacophony of a thousand screaming monkeys from the village cemetery.

\begin{tabular}{|l|l|l|}
\hline all Santayib... & was & the cacophony... \\
\hline token & identifyng proc. & value \\
\hline
\end{tabular}


Another subtype of the mental process is cognition, or thinking process. The verbs included in this subtype are think, remember, remind, know, and etc. In the data, the process of cognition in $\mathrm{T} 1$ is transferred into an attributive-relational process. This can be seen in the data below in which the verb "paham" ('understand'), a thinking process, is then realized into a main process of 'being' (was). "Was" in the T2 (target text) is the main verb to represent the relational process.

5. Boleh jadi Srintil belum faham benar makna lirik lagu itu.

\begin{tabular}{|l|l|l|l|l|}
\hline $\begin{array}{l}\text { Boleh } \\
\text { jadi }\end{array}$ & Srintil & belum & faham... & makna... \\
\hline & senser & & knowing proc. & Phenom. \\
\hline
\end{tabular}

It wasn't likely that she was able to fully fathom the meaning of the lyrics.

\begin{tabular}{|l|l|l|l|}
\hline It wasn't ... & she & was & \multicolumn{2}{|c|}{ able to fully... } \\
\hline & carrier & attributive proc. & attribute \\
\hline
\end{tabular}

However, it is seen that the meaning of "paham" is equal to the verb "fathom". This way reveals that "was" in the clause functions to be "an auxiliary" to mean "can". Thus, the change of the process is not there since the cognition process of "paham" ('understand') is maintained in its English version, "fathom". It can be concluded that the cognition process has no change in its translation.

The third subtype of mental process is affection, an emotion aspect. It covers the words like love, hate, like, dislike. The affection in the data is turned into an attributive relational process, as in the datum 6. The predicate as the process realization in T1 is the verb "rindu" ('to long'). The clause with affection process is changed into a relational clause with 
"were" as the main verb in the predicate of the target text. The meaning of 'to long' is then embodied into an adjective "impatient" in the translation.

6. Mereka sudah begitu rindu akan suara calung.

\begin{tabular}{|l|l|l|l|l|}
\hline Mereka & sudah & begitu & rindu & $\begin{array}{l}\text { akan suara } \\
\text { calung }\end{array}$ \\
\hline Senser & & $\begin{array}{l}\text { feeling } \\
\text { proc. }\end{array}$ & phenomenon \\
\hline
\end{tabular}

They were impatient to hear the calung ensemble

\begin{tabular}{|l|l|l|}
\hline They & were & Impatient... \\
\hline Carrier & attributive proc. & attribute \\
\hline
\end{tabular}

Thus, among four subtypes of mental process (perception, cognition, affection and volition), only perception and affection are changed into a different type of process. Most changes are identified in the clauses with a perception process. The changes are due to the translation strategies of transposition, and modulation. Another factor of the change is the use of metaphorical expression in the target text to realize a literal clause in the source.

\section{Conclusion}

A translation of clauses packed in mental process from Bahasa Indonesia into English in the novel has given an evidence that variation is possible. It opens a potential negotiation between the source and target texts. A target text is not always fully obedient to its source. In another way, a translator does not need to be dictated by an author to express the meaning. As long as the meaning is maintained, a translator has a free space to express it in his/her personal preference. 


\section{References}

Ahmad T. (2003). The dancer (Rene T. A.Lysloff- Translator). Jakarta: Lontar.

. (1982). Ronggeng Dhukuh Paruk. Jakarta: Gramedia Pustaka Utama.

Asruddin Barori Tou. (2008). An SFL-inspired framework of translation: a translational semiotic communication model. Journal of Modern Languages. 18: 15-40.

Baker, Mona \& Saldanha, Gabriela. 2009. Routledge Encyclopedia of Translation Studies ( $2^{\text {nd }}$ Edition). New York: Routledge. Taylor and Francis e-Library.

Budiman, Arif. 2009. Thematic Structure Shift in Obama's Inaugural Speech in Between English and Indonesian Versions (A Systemic Functional Grammar Approach)-Master Thesis-Unpublished. Yogyakarta: Graduate School, Faculty of Cultural Science, the University of Gadjah Mada.

Halliday, M.A.K. (1985). An introduction to functional grammar. London: Edward Arnolds.

Halliday, M.A.K. \& Hasan, R. (1994). Bahasa, konteks, dan teks: aspekaspek bahasa dala pandangan semiotika sosial. (Terjemahan Assruddin B.Tou). Yogyakarya: Gadjah Mada University Press. (The original was published in 1985 by Deakin University, Victoria).

Halliday, M.A.K., Matthiessen, C.M.I.M. (2004). An introduction to functional grammar (revised ed.). London: Arnolds.

Khristianto. 2013. The Various Realization of Relational Process between the Javanese and English : A Study Case of Transtivity Theory Look on Ronggeng Dukuh Paruk. Translation Conference 2013 (September 2013). Jakarta: LTBI, UNIKA Atmajaya

Lavid, Julia \& Arus, Jorge \& Moraton, Lara. 2009. Comparison and Translation: Towards a Combined Methodology for Contrastive Corpus Studies. International Journal of English Studies (IJES), Special Issue:2009. University of Murcia.

Lian, Zhangjun \& Jiang, Ting. 2014. A Study of Modality System in Chinese-English Legal Translation from the Perspective of SFG. Cross-Cultural Communication, Vol.4, No.3, pp.497-503, March 2014. www.cscanada.net

Manfredi, Marina. 2008. Translating Text and Context: Translation Studies and Systemic Functional Linguistics. 
Mao, Zan, Li, Na \& Xue, Jiao. 2014. Corpus Stylistic Analysis of Modal Verbs in Major Barbara and its Chinese Versions. Theory and Practice in Language Studies, Vol. No.1, pp-70-78, January 2014. Finland: Academy Publisher.

Newmark, Peter. (1988). A Textbook of Translation. London: Prentice Hall Europe.

Wulandari, Diyah Fitri. 2013. Thematic structure shift found in EnglishIndonesian Translation of Obama's speech in Indonesia University. Proceeding of Language Shift and Maintenance III (July 2-3, 2013) Revised Edition. Semarang: Master Program in Lingustics, Diponegoro University.

Yuli, Sun \& Yushan, Zhao. 2012. A Comparison of Transitivity System in English and Chinese. Cross-Cultural Communication, Vol.8, No.4, 2012, pp.75-80. www.cscanada.net 